\title{
Synthesis, Structure and Spectroscopic Properties of Oxovanadium Tris(3,5-dimethylpyrazolyl)borate Aroylthiourea Complexes
}

(Sintesis, Struktur dan Sifat Spektroskopi Kompleks Oksovanadium Tris(3,5-dwimetilpirazolil)borat Aroiltiourea)

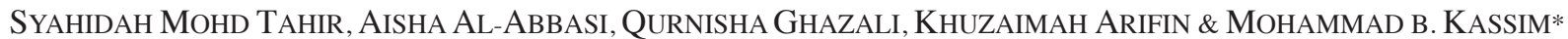

\begin{abstract}
Aroylthiourea ligands, 1-aroyl-3-cyclohexyl-3-methylthiourea $\left(H L_{1}\right)$, 1-(2-chloroaroyl)-3-cyclohexyl-3-methylthiourea $\left(H L_{2}\right), 1-(3-c h l o r o a r o y l)-3-c y c l o h e x y l-3-m e t h y l t h i o u r e a ~\left(H L_{3}\right)$ and 1-(4-chloroaroyl)-3-cyclohexyl-3-methylthiourea $\left(H L_{4}\right)$ were synthesized through a condensation reaction of methylcyclohexylamine and aroylisothiocyanate with a general formula $(\mathrm{X}-\mathrm{Ph})(\mathrm{CO}) \mathrm{NH}(\mathrm{CS}) \mathrm{N}\left(\mathrm{C}_{6} \mathrm{H}_{5}\right)\left(\mathrm{CH}_{3}\right)$ where $\mathrm{X}=\mathrm{H}, \mathrm{o}-\mathrm{Cl}, \mathrm{m}$-Cl and $\mathrm{p}$-Cl, fully characterized by CHNS micro elemental analysis, infrared spectroscopy, $U V$-visible, nuclear magnetic resonance $\left({ }^{1} \mathrm{H},{ }^{13} \mathrm{C}\right)$ and $\mathrm{X}$-ray crystallography. 1-(3-chloroaroyl)-3-cyclohexyl-3-methylthiourea $\left(H L_{3}\right)$ crystallized in the monoclinic system, $a=14.504(3), b=4.9599(11)$, $c=22.325(5) \AA, \beta=98.461(7)^{\circ}, Z=4$ and $V=1588.5(6) \AA$ with space group $P 2_{1} / c$. The IR spectra of the ligands exhibits the characteristic $v(C O)$ and $v(N-H)$ at range $1701-1640 \mathrm{~cm}^{-1}$ and $3317-3144 \mathrm{~cm}^{-1}$, respectively. Whereas the ${ }^{1} \mathrm{H}$ and ${ }^{13} \mathrm{C} N M R$ spectra shows the resonances for $\mathrm{N}-\mathrm{H}$ and $-\mathrm{CO}$ groups at range 8.3-8.5 and 160-163 ppm, respectively. A onepot reaction involving the aroylthiourea ligand, oxovanadium(IV) ion and potassium hydrotris(3,5-dimethylpyrazolyl) borate $\left(K_{T}^{*}\right)$ complex gave the desired [oxovanadium(IV)(tris(pyrazolyl)borate)(aroylthiourea)] complexes namely $T p^{*} V O L_{1}, T^{*} \mathrm{VOL}_{2}, \mathrm{Tp}^{*} \mathrm{VOL}_{3}$ and $\mathrm{Tp}^{*} \mathrm{VOL}_{4}$ and all complexes were characterized accordingly. X-ray study showed that $T p^{*} V_{1}$ adopted a monoclinic crystal, $a=3.415(2), b=19.463(3), c=14.22(3) \AA, \beta=107.411(4)^{\circ}, Z=4$ and $V=3542.7(11)$ $\AA$ with $P 2$ /c space group. The $V^{2+}$ center adopted a pseudo-octahedral geometry $O 2 N 3 S$, with the oxovanadium(IV) coordinated to the bidentate ligand $(\mathrm{X}-\mathrm{Ph})(\mathrm{CO}) \mathrm{NH}(\mathrm{CS}) \mathrm{N}\left(\mathrm{C}_{6} \mathrm{H}_{5}\right)\left(\mathrm{CH}_{3}\right)$ and tridentate Tp* ligands. The results showed that aroylthiourea ligands behave as bidentate chelate through $O$ and $S$ atom and the $T p^{*} C_{3 v}$ symmetry adds stabilization to the $\mathrm{VO}^{2+}$ through its protective tripodal geometry.
\end{abstract}

Keywords: Aroylthiourea; chelate; oxovanadium(IV); tris(pyrazolyl)borate; vanadyl

\section{ABSTRAK}

Ligan aroiltiourea, 1-aroil-3-sikloheksil-3-metiltiourea $\left(H L_{1}\right)$, 1-(2-kloroaroil)-3-sikloheksil-3-metiltiourea (HL $\left.{ }_{2}\right)$, 1-(3-kloroaroil)-3-sikloheksil-3-metiltiourea $\left(\mathrm{HL}_{3}\right)$ dan 1-(4-kloroaroil)-3-sikloheksil-3-metiltiourea $\left(\mathrm{HL}_{4}\right)$ telah disintesis melalui tindak balas kondensasi antara metilsikloheksilamina dan aroilisotiosianat dengan formula asas, $(X-P h)(C O)$ $\mathrm{NH}(\mathrm{CS}) \mathrm{N}\left(\mathrm{C}_{6} \mathrm{H}_{5}\right)\left(\mathrm{CH}_{3}\right)$ dengan $\mathrm{X}=\mathrm{H}, \mathrm{o}-\mathrm{Cl}, \mathrm{m}$-Cl dan $\mathrm{p}$-Cl. Pencirian penuh telah dilakukan dengan mikroanalisis unsur CHNS, spektroskopi inframerah, ultralembayung boleh nampak, resonans magnet nukleus $\left({ }^{1} \mathrm{H},{ }^{13} \mathrm{C}\right)$ serta kristalografi sinar-X. Ligan, 1-(3-kloroaroil)-3-sikloheksil-3-metiltiourea $\left(\mathrm{HL}_{3}\right)$ menghablur dalam sistem monoklinik, $a=14.504(3)$, $b=4.9599(11), c=22.325(5) \AA, \beta=98.461(7)^{\circ}, Z=4$ dan $V=1588.5(6)$ dengan kumpulan ruang $P 2_{1} / c$. Spektrum IR bagi kesemua ligan mempamerkan sifat $v(C O)$ dan $v(N-H)$ masing-masing dalam lingkungan 1701-1640 $\mathrm{cm}^{-1}$ dan 3317$3144 \mathrm{~cm}^{-1} . R M N{ }^{1} \mathrm{H}$ dan ${ }^{13} \mathrm{C}$ menunjukkan resonans bagi kumpulan $(\mathrm{N}-\mathrm{H})$ dan-CO masing-masing dalam lingkungan 8.3-8.5 dan 160-163 ppm. Tindak balas serentak melibatkan ligan aroiltiourea, ion oksovanadium(IV) dan kompleks kalium hidrotris(3,5-dimethilpirazolil)borat (KTp*) untuk membentuk kompleks yang diinginkan [oksovanadium(IV) (tris(pirazolil)borat)(aroiltiourea)] dinamakan $T p^{*} V O L_{1}, T p^{*} V O L_{2}, T p^{*} V O L_{3}$ dan $T p^{*} V O L_{4}$ telah berjaya disintesis dan dicirikan. Kristalografi sinar-X menunjukkan Tp*VOL mempunyai sistem hablur monoklinik, $a=3.415(2), b=19.463(3)$, $c=14.22(3) \AA, \beta=107.411(4)^{\circ}, Z=4$ dan $V=3542.7(11) \AA$ dengan kumpulan ruang $P 2_{I} / c$. Pusat VO ${ }^{2+}$ menyarankan geometri kompleks yang terbentuk adalah pseudo-oktahedral O2N3S dengan pusat oksovanadium(IV) berkoordinat dengan ligan bidentat $(\mathrm{X}-\mathrm{Ph})(\mathrm{CO}) \mathrm{NH}(\mathrm{CS}) \mathrm{N}\left(\mathrm{C}_{6} \mathrm{H}_{5}\right)\left(\mathrm{CH}_{3}\right)$ dan ligan tridentat $\mathrm{Tp}$ *. Ligan aroiltiourea bertindak sebagai pengkelat bidentat melalui atom $O$ dan $S$ dan ligan $T p^{*}$ yang bersimetri $C_{3 v}$ memberikan kestabilan kepada pusat VO ${ }^{2+}$ dengan geometri tripodal.

Kata kunci: Aroiltiourea; kelat; oksovanadium(IV); tris(pirazolil)borat; vanadil

\section{INTRODUCTION}

Aroylthiourea ligands display a wide range of biological activity such as anticancer (Saeed et al. 2010; Solinas et al. 2012), anti-phatogenic (Limban et al. 2011) and antibacterial (Mohamad Halim et al. 2011). The synthesis of aroylthiourea involves the substitution on 
the first and second nitrogen of thiourea functionality $((>\mathrm{N}-\mathrm{C}(\mathrm{S})-\mathrm{N}<)$ with aroyl group (Saeed et al. 2014). The versatility of the backbone of thiourea brings the development of various new compounds bearing thiourea with significant applications (Khairul et al.2016; Saeed et al. 2010; Shardin et al. 2017). Derivatives of thiourea are potentially very versatile ligands that able to coordinate to a range of metal center as neutral ligands, monoanion or dianion (Arslan et al. 2009). Oxygen and sulfur donor atom of aroylthiourea derivatives will coordinate to transition metal in monodentate or bidentate manner and has been considered as chelating agent. Metal complexes of aroylthiourea with $\mathrm{O}, \mathrm{S}$ donor atoms also exhibit a wide application such as antimicrobial (Alfallous \& Aburzeza 2015; Arslan et al. 2009), antibacterial (Yang et al. 2012) and catalysts (Gunasekaran \& Karvembu 2010; Gunasekaran et al. 2011; Khairul et al. 2014).

Coordination chemistry of oxovanadium(IV), oxovanadium(V) and dioxovanadium(V) has generated interest due to the model of vanadium complexes containing enzymes and serve as good oxidation catalysts as well as exhibit insulin mimetic agent (Mangalam \& Kurup 2009). However, oxovanadium complexes(IV) having sulfur donor ligand is not widely studied compare to $\mathrm{O}$ and $\mathrm{N}$ donor ligands (Parihar et al. 2012; Prasad et al. 2011; Yadava et al. 2012) except a few reports on structural studies and insulin-like activity of ONS ligand (Bai et al. 2010; Mangalam \& Kurup 2009). Oxovanadium (IV) complex that have vanadyl moiety $\mathrm{VO}^{2+}$ can coordinated to four or five donor atoms to form the $\mathrm{VOL}_{4}$ and $\mathrm{VOL}_{5}$ complexes (Mangalam \& Kurup 2009). Oxovanadium complexes can also coordinated with sixth donor atoms to form octahedral complex (Cotton \& Wilkinson 1966). The $\mathrm{VO}^{2+}$ moiety of oxovanadium(IV) complex forms stable coordination complexes with ligands attributed to the strong covalent vanadium-oxygen bonding. Thus, when vanadium ion forms bonding with other ligand, the influence of donor ligand on oxovanadium complex can be studied through reactivity of $\mathrm{V}-\mathrm{O}$ bond (Mangalam \& Kurup 2009). Complexes of oxovanadium(IV) with $\mathrm{O}, \mathrm{N}, \mathrm{S}$ donor atom are studied in the aspect of electronic interaction (Bai et al. 2010; Mangalam \& Kurup 2009; Yadava et al. 2012) and application in bioinorganic chemistry (Maia et al. 2009; Maurya et al. 2006; Prasad et al. 2011).

The attempts to isolate oxovanadium(IV) complexes of aroylthiourea $\left(\mathrm{VOL}_{2}\right)$ were not successful due to the instability of the product that decompose in the laboratory atmosphere. Therefore, tris(3,5-dimethyl)pyrazoylborate (Tp*) was employed in order to increase and control the stability of the V(IV) complexes.

Hydrotris(3,5-dimethyl-1H-pyrazol-1-yl)borate (Tp*) is a versatile class of anionic nitrogen donor ligands that form tridentate coordination with transition metals (Xing et al. 2007). Tp* that have three pyrazol rings can act as tridentate stabilizing agent by forming steric and electronic effects hence optimizes the reactivity of metal ion center (Pettinari 2004). The tripodal Tp* ligand have
$\mathrm{C}_{3 \mathrm{v}}$ symmetry geometry (Mark et al. 2012a; Wlodarczyk et al. 1996) and the presence of methyl group on position 3 and 5 of pyrazol rings give the stability and high steric effect to the ligand (Mark et al. 2012b). Tp* will coordinate to metal ion center through the three $\mathrm{N}$ atom from three pyrazol ring (Mark et al. 2013). Coordination chemistry of oxovanadium(IV) complexes with Tp* ligand has been studied and few reports on the application of the complex in biology process involving organisms (Bai et al. 2010; Collison et al. 1993; Etienne 1996; Xing et al. 2007a).

In this study, oxovanadium complexes with 1-(X-aroyl)-3-cyclohexyl-3-methylthiourea $(X=\mathrm{H}, o-\mathrm{Cl}$, $m-\mathrm{Cl}$ and $p-\mathrm{Cl})$ ligands and $\mathrm{Tp} *$ ancillary ligand were synthesized. The influence of chlorine $(\mathrm{Cl})$ substituent and its positions (ortho, meta and para) on the aroyl ring of aroylthiourea toward the structural properties of the ligands and consequently, the effects on the physical and chemical properties of the oxovanadium(IV) complexes are presented in this study.

\section{MATERIALS AND METHODS}

Derivatives of aroyl chloride $\left(X-\mathrm{C}_{6} \mathrm{H}_{4} \mathrm{COCl}\right)$ where $(X$ $=\mathrm{H}, o-\mathrm{Cl}, m-\mathrm{Cl}$ and $p-\mathrm{Cl}), \mathrm{N}$-methylcyclohexylamine $\left(\mathrm{C}_{6} \mathrm{H}_{11} \mathrm{NHCH}_{3}\right)$, ammonium thiocyanate $\left(\mathrm{NH}_{4} \mathrm{SCN}\right)$ were purchased from Sigma-Aldrich and used as received. Vanadyl sulphate hydrate $\left(\mathrm{VOSO}_{4}-\mathrm{xH}_{2} \mathrm{O}\right)$ were purchased from Alfa-Aesar and stored under inert gas. Tris(3,5dimethyl-1H-pyrazol-1-yl)borate potassium (KTp*) used in the experiment were synthesized using previously reported method (McCleverty et al. 1976; Wlodarczyk et al. 1996). All solvents were purchased from MERCK (reagent grade) and used without further purification.

Thin layer chromatography (TLC) was performed on silica gel plates from MERCK with dichloromethane/nhexane as eluent. Column chromatography was conducted using silica gel with pore size $0.06-0.20 \mathrm{~mm}$ purchased from MERCK. Infrared spectra were recorded using a Nicolet 6700 FTIR spectrophotometer in the range 4000 - $200 \mathrm{~cm}^{-1}$. The ${ }^{1} \mathrm{H}$ and ${ }^{13} \mathrm{C}$ NMR spectra in $\mathrm{CDCl}_{3}$ were acquired from JEOL JNM-ECP $400 \mathrm{MHz}$ and Varian Mercury $300 \mathrm{MHz}$. Electronic absorption spectra were obtained in dichloromethane on a UV-2450 PC SHIMADZU in the range 235 - $900 \mathrm{~nm}$. Elemental microanalyses for carbon, hydrogen and nitrogen (CHNS) were performed using a CARLO ERBA 1108 elemental analyzer. The mass spectra were recorded on a SHIMADZU QP5050A/ QP2010PLUS and were determined by electron impact (EI) technique. Single crystal structures were determined using X-Ray Diffractometer Bruker D8 Quest SC-XRD.

1-(X-aroyl)-3-cyclohexyl-3-methylthiourea $(X=\mathrm{H}$, $o-\mathrm{Cl}, m-\mathrm{Cl}$ and $p-\mathrm{Cl}$ ) ligands were prepared according to published literature method as shown in Scheme 1(a) (Kavak et al. 2009) with some adjustment. A solution of $\mathrm{R}$-aroyl chloride $(1.41 \mathrm{~g}, 0.01 \mathrm{~mol})$ in acetone was added dropwise to a suspension of potassium thiocyanate $(0.97 \mathrm{~g}$, $0.01 \mathrm{~mol})$ in acetone and the reaction mixture was stirred for $30 \mathrm{~min}$. A solution of $\mathrm{N}$-methylcyclohexylamine $(1.13 \mathrm{~g}$, 
$0.01 \mathrm{~mol}$ ) in acetone was added and the resulting mixture was stirred for another $2 \mathrm{~h}$. The solution was filtered and poured onto an ice-water mixture to give a white solid precipitate, filtered and washed with water. Then, ligands were purified by recrystallization from an ethanol solution. The structures of $\mathrm{HL}_{1}-\mathrm{HL}_{4}$ are shown in Figure 1. $\mathrm{HL}_{1}$ (1-aroyl-3-cyclohexyl-3-methylthiourea): Yield 71.1\%. Elemental CHNS analysis, \% found (\% calculated): C 64.93 (65.18); H 9.56 (7.29); N 10.84 (10.14) \& S 8.05 (11.60). Infrared spectrum $\left(\mathrm{cm}^{-1}\right): 3317 v(\mathrm{~N}-\mathrm{H}) ; 1683$ $v(\mathrm{C}=\mathrm{O}) \& 1227 v(\mathrm{C}=\mathrm{S})$. UV-Vis spectrum $\lambda_{\max } / \mathrm{nm}\left(\varepsilon \times 10^{4}\right.$ $\mathrm{M}^{-1} \mathrm{~cm}^{-1}$ ) in dichloromethane solution: $239 \mathrm{~nm}(22430) \&$ $281 \mathrm{~nm}$ (10560). HL (1-(2-chloroaroyl)-3-cyclohexyl-3methylthiourea): Yield 57.9\%. Elemental CHNS analysis, $\%$ found (\% calculated): C 57.93 (57.96); H 8.09 (6.16); N 9.20 (9.01) \& S 8.87 (10.32). Infrared spectrum $\left(\mathrm{cm}^{-1}\right)$ : $3132(\mathrm{~N}-\mathrm{H}) ; 1688(\mathrm{C}=\mathrm{O}) \& 1228(\mathrm{C}=\mathrm{S})$. UV-Vis spectrum $\lambda_{\max } / \mathrm{nm}\left(\varepsilon \times 10^{4} \mathrm{M}^{-1} \mathrm{~cm}^{-1}\right)$ in dichloromethane solution: $283 \mathrm{~nm}$ (5510) \& $345 \mathrm{~nm}$ (340). HL 3 (1-(3-chloroaroyl)3-cyclohexyl-3-methylthiourea): Yield $46.1 \%$ yield. Elemental CHNS analysis, \% found (\% calculated): C 57.93 (57.96); H 8.09 (6.16); N 9.20 (9.01) \& S 8.87 (10.32). Infrared spectrum $\left(\mathrm{cm}^{-1}\right): 3169(\mathrm{~N}-\mathrm{H}) ; 1691$ $(\mathrm{C}=\mathrm{O}) \& 1224(\mathrm{C}=\mathrm{S})$. UV-Vis spectrum $\lambda_{\max } / \mathrm{nm}\left(\varepsilon \times 10^{4}\right.$ $\mathrm{M}^{-1} \mathrm{~cm}^{-1}$ ) in dichloromethane solution: $240 \mathrm{~nm}$ (22850) \& $284 \mathrm{~nm}$ (11650). HL 4 (1-(4-chloroaroyl)-3-cyclohexyl-3methylthiourea): Yield 40.8\%. Elemental CHNS analysis, $\%$ found (\% calculated): C 58.19 (57.96); H 7.98 (6.16); N 9.24 (9.01) \& S 8.77 (10.32). Infrared spectrum $\left(\mathrm{cm}^{-1}\right)$ : $3144(\mathrm{~N}-\mathrm{H}) ; 1690(\mathrm{C}=\mathrm{O}) \& 1221(\mathrm{C}=\mathrm{S})$. UV-Vis spectrum $\lambda_{\max } / \mathrm{nm}\left(\varepsilon \times 10^{4} \mathrm{M}^{-1} \mathrm{~cm}^{-1}\right)$ in dichloromethane solution: 246 $\mathrm{nm}$ (34090).
The oxovanadium(IV) complexes were synthesized as shown in Scheme 1(b). Vanadyl sulphate hydrate $\left(\mathrm{VOSO}_{4}^{-}\right.$ $\left.\mathrm{xH}_{\mathrm{k}} \mathrm{O}, 0.163,1 \mathrm{mmol}\right)$ was dissolved in $\mathrm{H}_{2} \mathrm{SO}_{4}(10 \%, 1$ $\mathrm{mL}$ ) to form a blue solution. A methanolic solution of 1-( $X$-aroyl-3-cyclohexyl-3-methylthiourea $(2 \mathrm{mmol})$ was added and the $\mathrm{pH}$ of resulting green-blue solution was adjusted to $\mathrm{pH}$ 2-3 using a solution of sodium bicarbonate, $\mathrm{NaHCO}_{3}(1 \mathrm{M})$ to give a light blue precipitate immediately. Then, KTp* ligand $(0.33 \mathrm{~g}, 1 \mathrm{mmol})$ was added and the resulting mixture was filtered to remove the unwanted light-blue precipitate. The solvent was removed under vacuum and a mixture of water/chloroform was used to extract blue violet filtrate, which was the desired complex. The complex was purified by chromatography on silica gel using mixture of dichloromethane to n-hexane ratio of 5:1 as an eluent to obtain a greenish blue product. Tp*VOL 1 (Oxovanadium 1-(H-aroyl)-3-cyclohexyl-3methylthiourea hidrotris(3,5-dimethyl-1H-pyrazol-1$\mathrm{yl})$ ): Yield 28.6\%. Elemental CHNS analysis, \% found (\% calculated): C 56.80 (56.25); H 7.05 (6.61); N 18.34 (17.49) \& S N/A (4.99). Infrared spectrum $\left(\mathrm{cm}^{-1}\right): 2517$ (B-H Tp*); $958(\mathrm{~V}=\mathrm{O}) ; 1486(\mathrm{C}=\mathrm{O}) \& 645(\mathrm{C}-\mathrm{S})$. UV-Vis spectrum $\lambda_{\max } / \mathrm{nm}\left(\varepsilon \times 10^{4} \mathrm{M}^{-1} \mathrm{~cm}^{-1}\right)$ in dichloromethane solution: 248 (22830); 582 (35) \& 759 (45). MS (m/z): 364 [Tp*VO]; $544\left[\mathrm{Tp}^{*} \mathrm{VOL}_{1}\right]^{+}$with one pyrazolyl ring lost \& 639

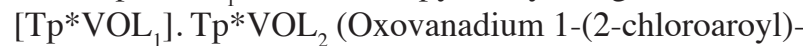
3-cyclohexyl-3-methylthiourea hidrotris(3,5-dimethyl-1Hpyrazol-1-yl)): Yield 18.4\%. Elemental CHNS analysis, \% found (\% calculated): C 52.94 (53.38); H 7.84 (6.12); N 16.37 (16.60) \& S 3.45 (4.75). Infared spectrum $\left(\mathrm{cm}^{-1}\right)$ : 2522 (B-H Tp*); $959(\mathrm{~V}=\mathrm{O}) ; 1484(\mathrm{C}=\mathrm{O})$ \& 645 (C-S). UVVis spectrum $\lambda_{\max } / \mathrm{nm}\left(\varepsilon \times 10^{4} \mathrm{M}^{-1} \mathrm{~cm}^{-1}\right)$ in dichloromethane<smiles>O=C(Cl)c1ccccc1</smiles>

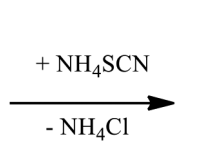<smiles>O=C(N=C=S)c1ccccc1</smiles><smiles>[X]c1ccc(C(=O)NC(=S)N(C)C2CCCCC2)cc1</smiles>

$\mathrm{HL}_{1}: X=\mathrm{H}$

$\mathrm{HL}_{2}: X=o-\mathrm{Cl}$

$\mathrm{HL}_{3}: X=m-\mathrm{Cl}$

$\mathrm{HL}_{4}: X=p-\mathrm{Cl}$

(a)

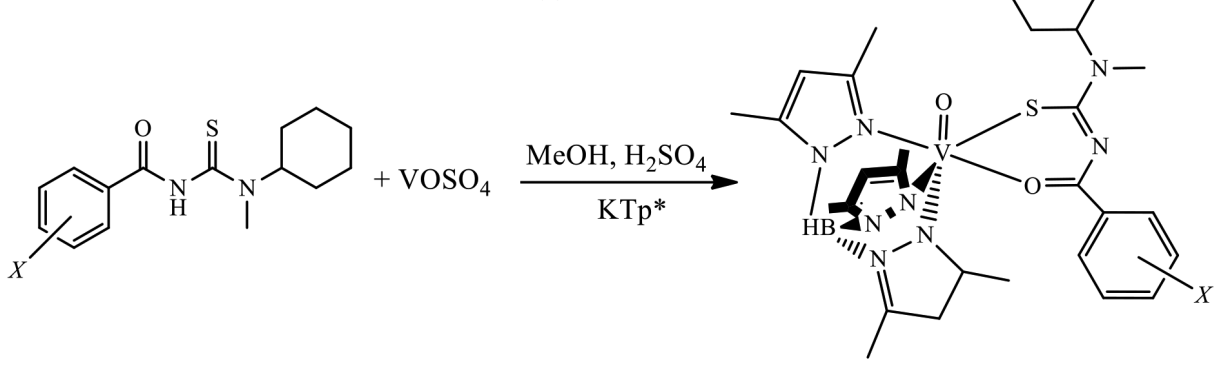

(b)

SCHEME 1. Schematic reaction for (a) synthesis of aroylthiourea ligand (b) synthesis of oxovanadium(IV) complexes with aroylthiourea and Tp* ligand 
<smiles>CN(C(=S)NC(=O)C1=CC=CCC1)C1CCCCC1</smiles><smiles>CC1CC(C(=O)NC(=S)N(C)C2C=CCCC2)CC=C1Cl</smiles><smiles>CN(C(=S)NC(=O)C1=C(Cl)C=CCC1)C1C=CCCC1</smiles>

$\mathrm{HL}_{2}$<smiles>CC1CC(C(=O)NC(=S)N(C)C2C=CCCC2)CC=C1Cl</smiles>

FIGURE 1 . The structure of aroylthiourea ligands with the atom numbering for NMR elucidation

solution: 272 (16110); 582 (11) \& 754 (16). MS (m/z): 364 [Tp*VO] \& 673 [Tp*VOL $\mathrm{Tp}_{2}$. Tp* $\mathrm{VOL}_{3}$ (Oxovanadium 1-(3-chloroaroyl)-3-cyclohexyl-3-methylthiourea hidrotris(3,5-dimethyl-1H-pyrazol-1-yl)): Yield 19.8\%. Elemental CHNS analysis, \% found (\% calculated): C 54.21 (53.38); H 8.61 (6.12); N 16.68 (16.60) \& S 3.50 (4.75). Infrared spectrum $\left(\mathrm{cm}^{-1}\right): 2520(\mathrm{~B}-\mathrm{H} \mathrm{Tp} *) ; 958$ $(\mathrm{V}=\mathrm{O}) ; 1484(\mathrm{C}=\mathrm{O}) \& 646(\mathrm{C}-\mathrm{S})$. UV-Vis spectrum $\lambda_{\max }$ ' $\mathrm{nm}\left(\varepsilon \times 10^{4} \mathrm{M}^{-1} \mathrm{~cm}^{-1}\right)$ in dichloromethane solution: 246 (8920); 581 (17) \& 760 (19). MS (m/z): 364 [Tp*VO] \& 673 $\left[\mathrm{Tp}^{*} \mathrm{VOL}_{3}\right]$. Tp*VOL 4 (Oxovanadium 1-(4-chloroaroyl)3-cyclohexyl-3-methylthiourea hidrotris(3,5-dimethyl-1Hpyrazol-1-yl)): Yield 23.7\%. Elemental CHNS analysis, \% found (\% calculated): C 51.00 (53.38); H 8.75 (6.12); N 16.40 (16.60) \& S 3.21 (4.75). Infrared spectrum $\left(\mathrm{cm}^{-1}\right)$ : 2521 (B-H Tp*); $959(\mathrm{~V}=\mathrm{O}) ; 1485(\mathrm{C}=\mathrm{O}) \& 646(\mathrm{C}-\mathrm{S})$. UVVis spectrum $\lambda_{\text {max }} / \mathrm{nm}\left(\varepsilon \times 10^{4} \mathrm{M}^{-1} \mathrm{~cm}^{-1}\right)$ in dichloromethane solution: 257 (15950); 582 (19) \& 759 (23). MS (m/z): 364 [Tp*VO] \& 673 [Tp* $\left.\mathrm{VOL}_{4}\right]$.

\section{RESULTS AND DISCUSSION}

All ligands were analyzed on the basis of CHNS elemental analysis, mass spectrometer and spectroscopic techniques (IR, UV-Vis and NMR). The spectroscopic properties of $\mathrm{HL}_{1}$ and its cobalt complex $\left(\mathrm{CoL}_{1}\right)$ were already reported (Tan et al. 2014), along with crystal structure of $\mathrm{HL}_{4}$ (Al-abbasi 2011). The structure of the ligand, 1-(3-chloroaroyl)-3cyclohexyl-3-methylthiourea ( $\mathrm{HL}_{3}$ ) and oxovanadium(IV) complex $\mathrm{Tp}^{*} \mathrm{VOL}_{1}$ were determined using single crystal X-ray diffractometer. The X-ray structure of oxovanadium(IV) complex, Tp* $\mathrm{VOL}_{1}$ confirmed that the amide proton of the aroylthiourea ligand was deprotonated upon complexation. Hence, oxovanadium(IV) metal coordinated with ligands $\mathrm{HL}_{1}-\mathrm{HL}_{4}$ through a bidentate chelate through $(\mathrm{O}, \mathrm{S})$ mode and a tridentate chelate through three $\mathrm{N}$ of Tp* to give neutral complexes Tp*VOLx $(x=$ $1-4)$.

The micro elemental analysis for $\mathrm{C}, \mathrm{H}$ and $\mathrm{N}$ atoms for both ligands and complexes agree with the empirical formulae of the expected molecules. The slightly higher percentage of $\mathrm{H}$ atom in all compounds might be due to sample were not completely dry during analysis and hence, some water molecule might have contributed to the reading.

The mass of the complexes molecule $\left(\mathrm{Tp}^{*} \mathrm{VOL}_{1}\right.$ $\mathrm{TP}^{*} \mathrm{VOL}_{4}$ ) were determined using electron impact (EI) mass spectroscopy by direct insertion mass spectrometer (DIMS) technique as shown by mass spectra of representative complex, Tp* $\mathrm{VOL}_{3}$ in Figure 2. Spectra showed the molecular mass for $\mathrm{Tp}^{*} \mathrm{VOL}_{3}$ at $\mathrm{m} / \mathrm{z} 673$. Fragmentation pattern of $\mathrm{Tp}^{*} \mathrm{VOL}_{3}$ complexes showed stepwise loss of fragments starting with 3,5-dimethyl-1H-pyrazol$1-y l$, followed by the tertiary amine moiety and lastly, the aroylthiourea ligand. The high intensity peak at $\mathrm{m} / \mathrm{z}$ 364 was also observed correspond to [Tp*VO], after the decomposition of the aroylthiourea ligand. This fragmentation pattern agrees with the X-ray structure of $\mathrm{Tp}^{*} \mathrm{VOL}_{1}$ that shows the aroylthiourea ligand was coordinated to the $\mathrm{VO}^{2+}$ centre via a bidentate chelate $(\mathrm{O}, \mathrm{S})$.

The IR spectra for all ligands are almost similar. Frequency for $v(\mathrm{~N}-\mathrm{H})$ was observed at range 3317-3144 $\mathrm{cm}^{-1}$. The band for $v(\mathrm{C}=\mathrm{S})$ present at range 1230-1220 $\mathrm{cm}^{-1}$. No significant difference for $v(\mathrm{C}=\mathrm{S})$ showed that the different position of $\mathrm{Cl}$ substituent group on aroyl moiety have no influence on $\mathrm{C}=\mathrm{S}$ moiety. All IR spectra of the ligands showed a strong band of $v(\mathrm{C}=\mathrm{O})$ in the range of 1701-1640 $\mathrm{cm}^{-1}$. However, aroylthiourea ligands $\left(\mathrm{HL}_{2}{ }^{-}\right.$ $\mathrm{HL}_{4}$ ) with $\mathrm{Cl}$ substituent group on aroyl moiety caused $v(\mathrm{C}=\mathrm{O})$ increase by $5-8 \mathrm{~cm}^{-1}$. Chloro group that act as electron withdrawing group will decrease the electron density on aroyl ring, thus decrease the electron density of $\mathrm{C}=\mathrm{O}$ by inductive effect through $\pi$ bond of aroyl ring. This effect increased the double bond characteristic of $\mathrm{C}=\mathrm{O}$ because the population of $\pi^{*} \mathrm{C}=\mathrm{O}$ orbital on aroylthiourea ligand was decreased. Hence, this would increase the frequency of $\mathrm{C}=\mathrm{O}$. Likewise, we can see that the variation in the position of $\mathrm{Cl}$ on aroyl ring of the aroylthiourea ligand have no significance effect on $v(\mathrm{C}=\mathrm{O})$, however the presence of $\mathrm{Cl}$ on aroyl ring itself gave some effect to the frequency of $\mathrm{C}=\mathrm{O}$ as discussed above. 


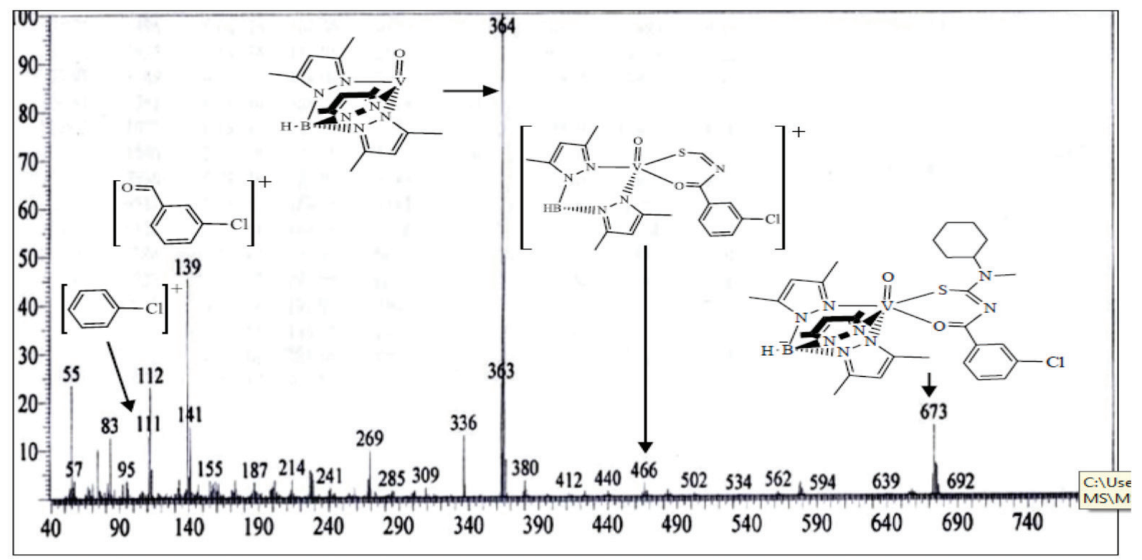

FIGURE 2. Mass Spectra of Tp*VOL3

The IR spectra of all complexes were slightly different compared with the IR spectra of the free ligands. The obvious different was the absence of $v(\mathrm{~N}-\mathrm{H})(3320-3110$ $\mathrm{cm}^{-1}$ ) in the spectra of the complexes that confirmed the aroylthiourea ligands were deprotonated in the oxovanadium(IV) complexes. The coordination of $\mathrm{VO}^{2+}$ to the carbonyl moiety caused the $\mathrm{v}(\mathrm{C}=\mathrm{O})$ band (1691$\left.1672 \mathrm{~cm}^{-1}\right)$ in free ligands, shifted to lower values after complexation (1490-1480 $\left.\mathrm{cm}^{-1}\right)$. The decrease in the $v(\mathrm{C}=\mathrm{O})$ value was due to the deprotonation that promote electron delocalization in the thioamide fragment (CONCS) (Tan et al. 2014). The disappearance of $v(\mathrm{C}=\mathrm{S})$ in the range of $1240-1210 \mathrm{~cm}^{-1}$ and the presence of new band with medium intensity at $646-645 \mathrm{~cm}^{-1}$ for $v(\mathrm{C}-\mathrm{S})$ in the spectra of the complexes, suggested the formation of $\mathrm{V}-\mathrm{S}$ bond via thiolation process as reported in the previous literature (Hernández et al. 2005; Mangalam \& Kurup 2009; Nguyen \& Abram 2007; Tan et al. 2014). In addition, the presence of a band at $2521-2517 \mathrm{~cm}^{-1}$ that corresponded to frequency of $\mathrm{B}-\mathrm{H}$ in all spectra of the complexes suggested the present of the Tp* moiety. The value was comparable with frequency of the B-H (2545 $\mathrm{cm}^{-1}$ ) reported for similar complex [Tp*VOCl(DMF) $\left(\mathrm{H}_{2} \mathrm{O}\right)$ ] (Kime-hunt et al. 1989). The sharp band observed at $1542 \mathrm{~cm}^{-1}$ indicated the presence of aromatic $\mathrm{C}=\mathrm{C}$ for pyrazol ring of Tp* ligands. Besides, all IR spectra of the complexes displayed a strong band in the range of 959-958 $\mathrm{cm}^{-1}$ corresponding to the frequency of $v(\mathrm{~V}=\mathrm{O})$ which is comparable with $v(\mathrm{~V}=\mathrm{O})\left(959 \mathrm{~cm}^{-1}\right)$ observed for previously reported oxovanadium(IV) trispyrazolylborate complex, $\mathrm{VO}\left(\mathrm{O}_{2}\right)(\mathrm{pzH})\left(\mathrm{HB}(\mathrm{pz})_{3}\right.$ (Xing et al. 2007a). The stretching band for $\mathrm{V}=\mathrm{O}$ of all complexes are practically similar and suggested that there is no influence from structural variations of aroylthiourea ligand toward the $\mathrm{V}=\mathrm{O}$ moiety.

The UV-Vis spectra for both ligands and complexes were collected in dichloromethane solution. The ligands showed the absorption bands at around 235-269 nm and was assigned to the $\pi \rightarrow \pi^{*}$ transition of the aromatic ring. The absorption bands at around 260-297 $\mathrm{nm}$ and 319-353 nm were attributed to the $\mathrm{n} \rightarrow \pi^{*}$ transition of
$\mathrm{C}=\mathrm{O}$ and $\mathrm{C}=\mathrm{S}$, respectively. The effect of $\mathrm{Cl}$ substituent on different positions were observed on $\mathrm{C}=\mathrm{O}$ bands for $\mathrm{HL}_{3}$ and $\mathrm{HL}_{4}$ at 240 and $246 \mathrm{~nm}$, respectively, but no significant effect was observed for $\mathrm{HL}_{2}$. The withdrawing effect of $\mathrm{Cl}$ group created an inductive effect to the aroyl ring, thus the hypsochromic effect shifted the $\mathrm{C}=\mathrm{O}$ band to shorter wavelength compared with that of $\mathrm{HL}_{1}(281 \mathrm{~nm})$. Moreover, the transition of $\mathrm{n} \rightarrow \pi^{*}$ were observed in UV-Vis spectra of $\mathrm{HL}_{2}(283,345 \mathrm{~nm})$ and $\mathrm{HL}_{3}(284 \mathrm{~nm})$ but was absence in spectrum of $\mathrm{HL}_{4}$. The stronger inductive effect of $\mathrm{Cl}$ group at the ortho position of aroyl moiety in $\mathrm{HL}_{4}$ resulted in hypsochromic shift causing the $n \rightarrow \pi^{*}$ band not to be observed in $\mathrm{HL}_{4}$.

UV-Vis spectra of complexes show a strong and broad absorption bands around 246-271 nm, which were assigned to $\pi \rightarrow \pi^{*}$ of aroyl ring of the aroylthiourea ligand, $n \rightarrow \pi^{*}$ transitions of $\mathrm{C}=\mathrm{O}$ and the aromatic chromophore of $\mathrm{Tp}^{*}$ ligand (Li et al. 2009). UV-Vis spectra of all complexes also showed the present of $d$ - $d$ transition in the visible region at 581 and $760 \mathrm{~nm}$. All UV-Vis spectra complexes also showed the present of three absorption bands for the $d$ - $d$ transitions in the visible range, $400-900 \mathrm{~nm}$. These low intensity band are indicative of the presence of $\mathrm{d} \pi-\mathrm{d} \pi$ transitions which is forbidden according to Laporte rule (Tan et al . 2014). There are two absorption bands at 582 and $755 \mathrm{~nm}$ and a shoulder at around $410 \mathrm{~nm}$ that corresponded to the transition of $d\left(z^{2}\right) \rightarrow d(x y)$ and $d\left(z^{2}\right) \rightarrow d(y z)$ transitions, respectively. There is no observable difference in the spectra of the complexes with the variation in the position $\mathrm{Cl}$ group on the aroyl moiety of aroylthiourea ligands.

The crystal structure of $\mathrm{HL}_{3}$ obtained from this study will be used to discuss the effect of different position of $\mathrm{Cl}$ atom toward structural properties of the ligands. The experimental details for the X-ray data and structure refinement parameters for ligand $\mathrm{HL}_{3}$ are summarized in Table 1. In the structure of $\mathrm{HL}_{3}$, the aroyl moiety of adopted an trans conformation with respect to thiono CS group across a partially double $\mathrm{N} 1-\mathrm{C} 8$ bond (Figure 3 ), with the torsion angle, C7-N1-C8-S1 of 126.7(15), comparative to that 1-aroyl-(3-propyl-3-methyl)thiourea (Tan et al. 2014) and 1-(4-chloroaroyl)-3-(cyclohexyl)-3- 
methylthiourea, $\mathrm{HL}_{4}$ (Al-abbasi et al. 2011). The N2-C8 bond $(1.320(17) \AA$ ) is shorter compared with a typical N-C single bond (1.479 $\AA$ ) (Rauf et al. 2009). Meanwhile the S1-C8 bond length $(1.715(15) \AA)$ is longer than a normal $\mathrm{C}=\mathrm{S}$ bond (1.6 $\AA$ ) (Wiberg \& Wang 2011). The O1-C7 retained the double bond character $(1.25 \AA)$ with a bond length 1.212(18) $\AA$. These observations were in accordance with the IR spectra observation that suggested an electron delocalization in the $\mathrm{N}-\mathrm{C}(\mathrm{S})-\mathrm{NH}-\mathrm{C}(\mathrm{O})$ fragment (Tan et al 2014). In addition, the $\mathrm{Cl}$ at meta position of aroyl ring have stronger influence as illustrated by $0.1 \AA$ increased in the bond length of $\mathrm{C}=\mathrm{S}(1.715(15) \AA)$ of $\mathrm{HL}_{3}$, compared to $(0.08 \AA)$ for $\mathrm{C}=\mathrm{S}$ bond of $\mathrm{HL}_{4}(1.687$ (4) $\AA$ ) in which the $\mathrm{Cl}$ at ortho position (Al-abbasi et al. 2011). Thus, the position of the $\mathrm{Cl}$ atom on the benzene ring of the aroyl moiety have some influence on $\mathrm{C}=\mathrm{S}$ moiety of aroylthiourea ligand, although the observations were not significance in spectroscopy data. All bond lengths of $\mathrm{HL}_{3}$ ligands are also comparable with that of reported for other thiourea derivatives (Al-abbasi et al. 2011; Tan et al. 2014). In the packing diagram of $\mathrm{HL}_{3}$ (Figure 4), the centrosymmetry structures forms columns down the $b$-axis. In the crystal structure of $\mathrm{HL}_{3}$, the molecules was further stabilized by the presence of intermolecular hydrogen $\mathrm{N}-\mathrm{H} \cdots \mathrm{S}$ bonds (2.76 $\AA$ ) as shown in the packing diagram.

The crystal data and structure refinement parameter for $\mathrm{Tp}^{*} \mathrm{VOL}_{1}$ are listed in Table 2. The molecular structure of oxovanadium 1-(H-aroyl)-3-cyclohexyl-3-methylthiourea hidrotris(3,5-dimethyl-1H-pyrazol-1-yl), Tp* VOL 1 (Figure 5) exhibited the pseudo-octahedral geometry $O 2 N 3 S$ where oxovanadium(IV) complex bearing bidentate $(\mathrm{O}, \mathrm{S})$ ligand of the 1-aroyl-3-cyclohexyl-3-methylthiourea $\left(\mathrm{HL}_{1}\right)$ and the tridentate ligand, Tp* $(\mathrm{N}, \mathrm{N}, \mathrm{N})$. The $\mathrm{O} 2$ and $\mathrm{S} 1$ atoms of the deprotonated aroylthiourea and two of the $\mathrm{N}$ atoms (N5 and N7) of the Tp*, occupy equatorial positions, whilst the terminal oxo (O1) and the third nitrogen atom of Tp* (N3) occupy axial positions. The $\mathrm{V}=\mathrm{O}$ bond distances of $\mathrm{Tp}^{*} \operatorname{VOL}_{1}(1.594(3) \AA$ ) was shorter and comparable to the

TABLE 1. Crystal data and refinement parameters for the ligand $\mathrm{HL}_{3}$

\begin{tabular}{|c|c|}
\hline Subject & $\mathrm{HL}_{3}$ \\
\hline Empirical formulae & $\mathrm{C}_{15} \mathrm{H}_{19} \mathrm{ClN}_{2} \mathrm{OS}$ \\
\hline Formula weight & 310.83 \\
\hline Temperature/K & $296(2)$ \\
\hline Crystal system & Monoclinic \\
\hline Space group & $\mathrm{P} 2_{1} / \mathrm{c}$ \\
\hline $\mathrm{a} / \AA$ & $14.504(3)$ \\
\hline $\mathrm{b} / \AA$ & $4.9599(11)$ \\
\hline c/ $\AA$ & $22.325(5)$ \\
\hline$\alpha /{ }^{\circ}$ & 90 \\
\hline$\beta /^{\circ}$ & $98.461(7)$ \\
\hline$\gamma /{ }^{\circ}$ & 90 \\
\hline Volume/Å & $1588.5(6)$ \\
\hline $\mathrm{Z}$ & 4 \\
\hline$\rho \operatorname{calcg} / \mathrm{cm}^{3}$ & 1.300 \\
\hline$\mu / \mathrm{mm}^{-1}$ & 0.369 \\
\hline $\mathrm{F}(000)$ & 656.0 \\
\hline Crystal size $(\mathrm{mm})$ & $0.07 \times 0.48 \times 0.28$ \\
\hline Radiation & $\operatorname{MoK} \alpha(\lambda=0.71073)$ \\
\hline $2 \Theta$ range for data collection & 7.38 to 50.02 \\
\hline Goodness-of-fit on $\mathrm{F}^{2}$ & 1.155 \\
\hline Independent reflections/Rint & $2228[$ Rint $=0.0670$, Rsigma $=$ N/A $]$ \\
\hline Data/restraints/parameters & $2228 / 0 / 183$ \\
\hline Final $R$ indexes $[I>2 \sigma(I)]$ & $\mathrm{R}_{1}=0.1650, \mathrm{wR}_{2}=0.4472$ \\
\hline Final $\mathrm{R}$ indexes [all data] & $\mathrm{R}_{1}=0.2099, \mathrm{wR}_{2}=0.4801$ \\
\hline
\end{tabular}

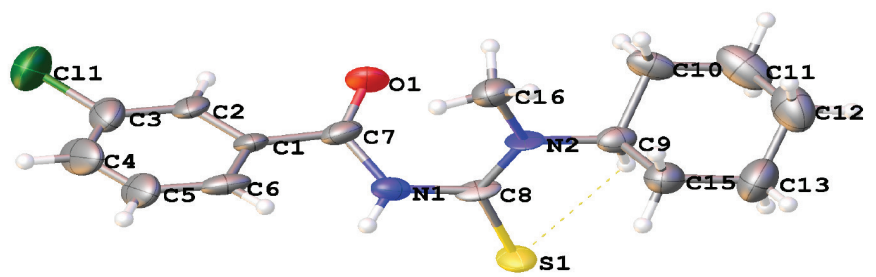

FIGURE 3 . The crystal structure of $\mathrm{HL}_{3}$ drawn at $50 \%$ probability ellipsoid with the atom numbering scheme 


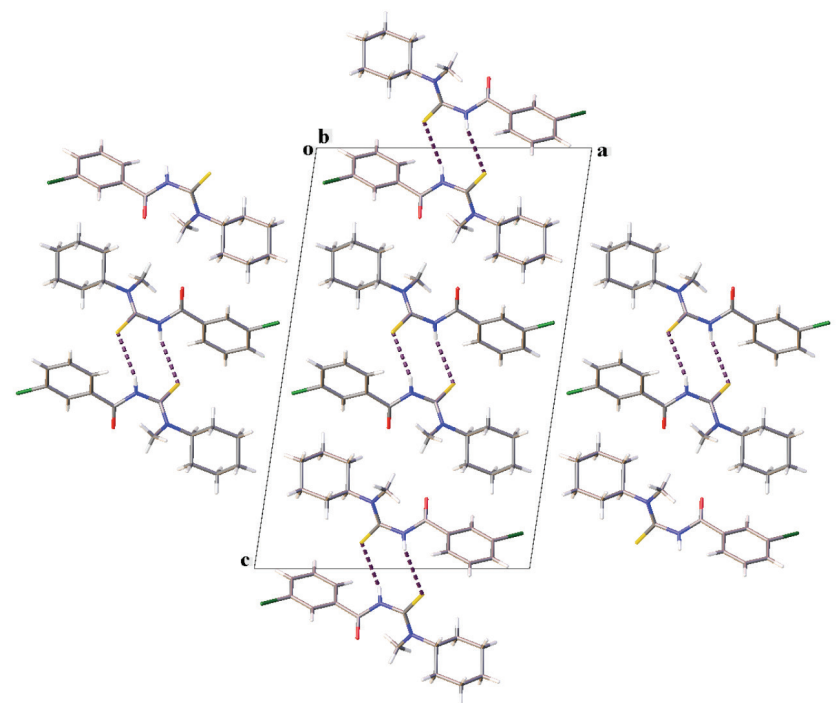

FIGURE 4. Packing diagram of $\mathrm{HL}_{3}$ viewed down the $b$-axis

TABLE 2. Crystal data and refinement parameters for the complex Tp*VOL

\begin{tabular}{|c|c|}
\hline Subject & $\mathrm{Tp}^{*} \mathrm{VOL}_{1}$ \\
\hline Empirical formulae & $\mathrm{C}_{30} \mathrm{H}_{41} \mathrm{BN}_{8} \mathrm{O}_{2} \mathrm{SV} \cdot \mathrm{CH}_{3} \mathrm{CN}$ \\
\hline Formula weight & 680.6 \\
\hline Temperature/K & $298(2)$ \\
\hline Crystal system & Monoclinic \\
\hline Space group & $\mathrm{P} 2 / \mathrm{c}$ \\
\hline a/ $\AA$ & $3.415(2)$ \\
\hline $\mathrm{b} / \AA$ & $19.463(3)$ \\
\hline c/ $\AA$ & $14.220(3)$ \\
\hline$\alpha /^{\circ}$ & 90 \\
\hline$\beta /{ }^{\circ}$ & $107.411(4)$ \\
\hline$\gamma / /^{\circ}$ & 90 \\
\hline Volume/Á & $3542.7(11)$ \\
\hline $\mathrm{Z}$ & 4 \\
\hline @calcg $/ \mathrm{cm}^{3}$ & 1.199 \\
\hline$\mu / \mathrm{mm}^{-1}$ & 0.376 \\
\hline $\mathrm{F}(000)$ & 1348 \\
\hline Crystal size(mm) & $0.42 \times 0.27 \times 0.26$ \\
\hline$\Theta$ range for data collection & 1.83 to 23.29 \\
\hline Goodness-of-fit on $\mathrm{F}^{2}$ & 1.155 \\
\hline Independent reflections/Rint & $2228[$ Rint $=0.0670$, Rsigma $=$ N/A $]$ \\
\hline Data/restraints/parameters & $5095 / 0 / 419$ \\
\hline Final $R$ indexes $[I>2 \sigma(I)]$ & $\mathrm{R}_{1}=0.0630 \mathrm{wR} 2=0.1642$ \\
\hline
\end{tabular}

reported values of [Tp*VO(acac)] (1.596(2) $\mathrm{A})$ (Beddoes et al. 1990), [TpVO(ph-acac)] (1.603(8) $\AA$ ) (Xing et al. $2007 \mathrm{~b})$ and that of $[\mathrm{Tp} * \mathrm{VO}(\mathrm{Cl})(\mathrm{DMF})](1.649(5) \AA$ (Kimehunt et al. 1989). Tp*VOL ${ }_{1}$ crystal structure confirms that the aroylthiourea ligands are deprotonated and coordinated to the vanadium ion through the $\mathrm{S}$ and $\mathrm{O}$ atoms; generating a planar six-membered chelating ring. The O2- V1-S1 angle (87.76(9) $\AA$ ) showed that there is a slight distortion from a regular octahedral arrangement of sulphur and oxygen atoms around the vanadium metal center. The bonding characteristic in the chelate rings is best described with an extended $\pi$-system. The corresponding $\mathrm{C}-\mathrm{O}$ and $\mathrm{C}-\mathrm{S}$ bonds, in the coordinated ligand for oxovanadium

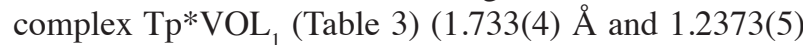
$\AA$, respectively) are longer than those in the free ligand $\mathrm{HL}_{1}$ (1.667(4) $\AA$ and 1.223(4) $\AA$, respectively. The bond lengths of N1-C7 and N1-C8 (1.300(5) $\AA$ and 1.361(5) $\AA$, respectively) were shorter than in the free ligand (1.361(5) $\AA$ and $1.408(5) \AA$, respectively). It is evident that there is an extensive delocalization of electrons inside the 


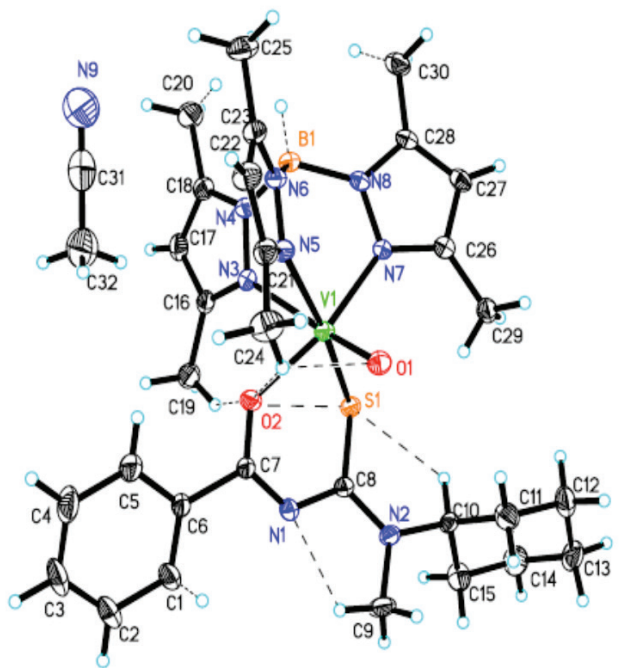

FIGURE 5. The molecular structure of complex $\mathrm{Tp}^{*} \mathrm{VOL}_{1}$ drawn at $30 \%$ probability ellipsoid with the atom numbering scheme. The dotted line indicated intramolecular hydrogen bonds

TABLE 3. Selected bond distances of oxovanadium complex, Tp*VOL $\mathrm{V}_{1}$ compared to their corresponding free ligand, $\mathrm{HL}_{1}$

\begin{tabular}{lccccc}
\hline & S1-C-8 & O2-C7 & N1-C7 & N1-C8 & N2-C8 \\
\hline Tp*VOL $_{1}$ & $1.733(4)$ & $1.2373(5)$ & $1.300(5)$ & $1.361(5)$ & $1.331(5)$ \\
$\mathrm{HL}_{1}$ & $1.667(4)$ & $1.223(4)$ & $1.361(5)$ & $1.408(5)$ & $1.331(5)$ \\
\hline
\end{tabular}

six-membered rings in the complex. Thus, considerable $\pi$-electron density is transferred to the chelate ring upon complexation. This is due to the coordination effect of the deprotonated aroylthiourea ligand that formed a partial double bond character in the $\mathrm{C}-\mathrm{N}$ bonds. The elongation of $\mathrm{C}-\mathrm{S}$ and $\mathrm{C}-\mathrm{O}$ and the shortening of $\mathrm{N}-\mathrm{C}$ bond lengths, observed in $\mathrm{Tp}^{*} \mathrm{VOL}_{1}$ was in agreement with other aroylthiourea metal complexes (Hernández et al. 2005; Nguyen \& Abram 2007). The molecular structure of the complex agreed with elemental analysis for CHNS, spectroscopic (IR, UV-vis) and mass spectrometry data showing the vanadium atom in a distorted octahedral coordination geometry.

The ${ }^{1} \mathrm{H}$ and ${ }^{13} \mathrm{C}$ NMR signals of aroylthiourea ligands were collected in Tables 4 and 5, respectively. The NMR spectra of $\mathrm{HL}_{1}$ were not recorded since the data were reported previously by Tan et al. (2014). The numbering atom for NMR elucidation showed in Figure 2.

The ${ }^{1} \mathrm{H}$ and ${ }^{13} \mathrm{C}$ NMR spectra of the ligands showed almost similar chemical shift for cyclohexyl moiety on amine group in the range of $1.05-2.00 \mathrm{ppm}$ for ${ }^{1} \mathrm{H}$ and 25-35 ppm for ${ }^{13} \mathrm{C}$. Proton $\mathrm{H} 9$ (4.7-4.9 ppm) shifted to downfield due to the deshielding effect of the $\mathrm{N}$ atom where a normal chemical shift for $\mathrm{sp}^{3} \mathrm{CH}$ is $1.4-1.7 \mathrm{ppm}$ in the range of 6.9-8.1 ppm. Splitting patterns of the peak are different according to the position of $\mathrm{Cl}$ on the aroyl ring. The chemical shift for $\mathrm{C}=\mathrm{O}(\mathrm{C} 7 / 160-163 \mathrm{ppm})$ and $\mathrm{C}=\mathrm{S}$ (C8/178-179 ppm) were most downfield positions because of the electronegativity effect of the $\mathrm{O}$ and $\mathrm{S}$ atoms toward carbon that is attached to it. Besides, the downfield shift

TABLE 4. ${ }^{1} \mathrm{H}$ NMR data of the aroylthiourea ligands

\begin{tabular}{|c|c|c|c|c|c|c|c|c|c|c|c|c|}
\hline \multirow{2}{*}{ Compound } & \multicolumn{12}{|c|}{ Chemical Shift, $\delta(\mathrm{ppm})$} \\
\hline & H1 & $\mathrm{H} 2$ & H3 & $\mathrm{H} 4$ & H5 & H9 & H10 & H11,H13 & $\mathrm{H} 12$ & H14 & H15 & $\mathrm{NH}$ \\
\hline \multirow[t]{2}{*}{$\mathrm{HL}_{2}$} & -- & $7.37 \mathrm{t}$ & $7.60 \mathrm{t}$ & $7.30 \mathrm{~m}$ & $7.37 \mathrm{t}$ & $4.83 \mathrm{t}$ & $1.95 \mathrm{~s}$ & $1.41 \mathrm{~m}$ & $1.18 \mathrm{~d}$ & $1.81 \mathrm{~d}$ & $3.09 \mathrm{~s}$ & $8.37 \mathrm{~s}$ \\
\hline & & $(1 \mathrm{H})$ & $(1 \mathrm{H})$ & $(1 \mathrm{H})$ & $(1 \mathrm{H})$ & $(1 \mathrm{H})$ & $(2 \mathrm{H})$ & $(4 \mathrm{H})$ & $(2 \mathrm{H})$ & $(2 \mathrm{H})$ & $(3 \mathrm{H})$ & $(1 \mathrm{H})$ \\
\hline \multirow[t]{2}{*}{$\mathrm{HL}_{3}$} & $7.76 \mathrm{~s}$ & -- & $7.63 \mathrm{~d}$ & $7.36 \mathrm{t}$ & $7.50 \mathrm{~d}$ & $4.86 \mathrm{t}$ & $1.95 \mathrm{~d}$ & $1.40 \mathrm{~m}$ & $1.11 \mathrm{~d}$ & $1.81 \mathrm{~d}$ & $3.00 \mathrm{~s}$ & $8.38 \mathrm{~s}$ \\
\hline & $(1 \mathrm{H})$ & & $(1 \mathrm{H})$ & $(1 \mathrm{H})$ & $(1 \mathrm{H})$ & $(1 \mathrm{H})$ & $(2 \mathrm{H})$ & $(4 \mathrm{H})$ & $(2 \mathrm{H})$ & $(2 \mathrm{H})$ & $(3 \mathrm{H})$ & $(1 \mathrm{H})$ \\
\hline \multirow[t]{2}{*}{$\mathrm{HL}_{4}$} & $7.78 \mathrm{~d}$ & $7.46 \mathrm{~d}$ & -- & $7.46 \mathrm{~d}$ & $7.78 \mathrm{~d}$ & $4.94 p$ & $2.18 \mathrm{~m}$ & $1.47 \mathrm{~m}$ & $1.15 \mathrm{~d}$ & $1.87 \mathrm{~d}$ & $3.09 \mathrm{~s}$ & $8.49 \mathrm{~s}$ \\
\hline & $(1 \mathrm{H})$ & $(1 \mathrm{H})$ & & $(1 \mathrm{H})$ & $(1 \mathrm{H})$ & $(1 \mathrm{H})$ & $(2 \mathrm{H})$ & $(4 \mathrm{H})$ & $(2 \mathrm{H})$ & $(2 \mathrm{H})$ & $(3 \mathrm{H})$ & $(1 \mathrm{H})$ \\
\hline
\end{tabular}


TABLE $5 .{ }^{13} \mathrm{C}$ NMR data of the aroylthiourea ligands

\begin{tabular}{|c|c|c|c|c|c|c|c|c|c|c|c|c|}
\hline \multirow{2}{*}{ Compound } & \multicolumn{12}{|c|}{ Chemical Shift, $\delta$ (ppm) } \\
\hline & $\mathrm{C} 1$ & $\mathrm{C} 2$ & $\mathrm{C} 3$ & $\mathrm{C} 4$ & $\mathrm{C} 5$ & C6 & $\mathrm{C} 7$ & $\mathrm{C} 8$ & C9 & $\mathrm{C} 10, \mathrm{C} 14$ & $\mathrm{C} 11, \mathrm{C} 13$ & $\mathrm{C} 15$ \\
\hline $\mathrm{HL}_{2}$ & 132.47 & 130.61 & 133.50 & 127.31 & 130.36 & 132.47 & 161.82 & 178.04 & 63.17 & 29.03 & 25.46 & 35.52 \\
\hline $\mathrm{HL}_{3}$ & 128.21 & 134.31 & 132.97 & 130.21 & 125.83 & 135.13 & 160.48 & 179.39 & 63.26 & 29.10 & 25.54 & 35.39 \\
\hline $\mathrm{HL}_{4}$ & 129.4 & 129.4 & 139.50 & 129.4 & 129.4 & 131.20 & 162.36 & 179.26 & 63.51 & 29.26 & 25.57 & 30.50 \\
\hline
\end{tabular}

was also due to the exchange in electron density between the $\mathrm{CO}$ and $-\mathrm{NH}$ - groups through resonance (Tan et al. 2014). However, there is not much difference observed on the chemical shift of $\mathrm{C}=\mathrm{O}$ and $\mathrm{C}=\mathrm{S}$ for ligands $\mathrm{HL}_{1}-\mathrm{HL}_{4}$ with different positions for the $\mathrm{Cl}$ atom on the aroyl ring of the aroylthiourea ligand that suggested the positions of the $\mathrm{Cl}$ atom has no influence on $\mathrm{C}=\mathrm{O}$ and $\mathrm{C}=\mathrm{S}$ groups.

The NMR for oxovanadium complexes was not collected because $\mathrm{VO}^{2+}$ ion has $d^{l}$ system and the electronic configuration in the neutral state is $[\mathrm{Ar}] 3 \mathrm{~d}^{1}$ (Kripal \& Shukla 2009). The present of an unpaired electron in the $d$ orbital of the $\mathrm{VO}^{2+}$ ion give a paramagnetic characteristic to the oxovanadium(IV) complexes and renders the collection of NMR spectrum of the complex not possible with a standard procedure.

\section{CONCLUSION}

Octahedral oxovanadium(IV) complexes with 1-( $X$-aroyl)3-cyclohexyl-3-methylthiourea $(X=\mathrm{H}, o-\mathrm{Cl}, m-\mathrm{Cl}$ and $p$-Cl) ligands were successfully synthesized. The aroylthiourea ligands coordinate to the $\mathrm{VO}^{2+}$ ion through a bidentate os chelate coordination mode. The tripodal ligand hydrotris (3,5-dimethyl-1H-pyrazol-1-yl)borate (Tp*) served as stabilizing agent coordinated to the $\mathrm{VO}^{2+}$ ion through the three nitrogen atoms of the pyrazol rings. The positions of the $\mathrm{Cl}$ atom on the aroyl ring of aroylthiourea ligand have no significant effects on $\mathrm{VO}^{2+}$ metal center.

\section{ACKNOWLEDGEMENTS}

The authors would like to thank the Ministry of Higher Higher Education (MOHE), Malaysia for MyBrain S.M.T scholarship and the Ministry of Science and Technology, Malaysia for ERGS/1/2013/TK07/UKM/02/2 research grant and Universiti Kebangsaan Malaysia for providing facilities and research grants (AP-2012-009 and DLP-2013001).

\section{REFERENCES}

Al-Abbasi, A.A., Yamin, B.M. \& Kassim, M.B. 2011. 1-(4-Chlorobenzoyl)-3-cyclohexyl-3-methylthiourea. Acta Crystallographica Section E Structure Reports Online 67(8): 1891.

Alfallous, K.A. \& Aburzeza, M.M. 2015. Synthesis, characterization, biological activity and use of thiourea derivative (PhTTU) studies of Cd(II) ion complex. International Journal of Science and Research 4(6): 350-352.
Arslan,H., Duran, N., Borekci, G., Ozer, C.K. \& Kabay, C. 2009. Antimicrobial activity of some thiourea derivatives and their nickel and copper complexes. Molecules 14(1): 519-527.

Bai, F.Y., Li, X.T., Zhu, G.S. \& Xing, Y.H. 2010. Synthesis and structure of a new scorpionate-dithio carboxyl oxovanadium complex and an organic dithio carboxyl compound. Spectrochimica Acta Part A: Molecular and Biomolecular Spectroscopy 75(5): 1388-1393.

Beddoes, R.L., Collison, D., Mabbs, F.E. \& Passand, M.A. 1990. Synthesis and charatcterization of some -diketonate derivatives of hydrotris(3,5-dimethylpyrazolyl)borato oxovanadium(IV). The crystal and molecular structure of hydrotris(3,5-dimethylpyrazolyl)borato pentane-2,4-dionato oxovanadium(IV). Polyhedron 9(20): 2483-2489.

Collison, D., Eardley, D.R., Mabbs, F.E., Powell, A.K. \& Scott, S. 1993. Synthesis, crystallographic and spectroscopic characterization, and magnetic properties of mixed-ligand oxovanadium(IV) hydrotris(3,5-dimethylpyrazolyl)borate complexes. Inorganic Chemistry 32(5): 664-671.

Cotton, F.A. \& Wilkinson, G. 1966. Advanced Inorganic Chemistry. New York: John Wiley and Sons. pp. 409-412.

Etienne, M. 1996. Hydridotris (pyrazolyl) borato complexes of the group 5 metals: Inorganic and organometallic chemistry. Coordination Chemistry Reviews 156: 201-236.

Gunasekaran,N. \& Karvembu, R.2010. Synthesis, characterization, and catalytic applications of $\mathrm{Ru}(\mathrm{III})$ complexes containing $\mathrm{N}$ - [di(alkyl/aryl)carbamothioyl]benzamide derivatives and triphenylphosphine/triphenylarsine. Inorganic Chemistry Communications 13(8): 952-955.

Gunasekaran, N., Remya, N., Radhakrishnan, S. \& Karvembu, R. 2011. Ruthenium(II) carbonyl complexes with N -[di(alkyl/aryl)carbamothioyl]benzamide derivatives and triphenylphosphine as effective catalysts for oxidation of alcohols. Journal of Coordination Chemistry 64(3): 491-501.

Hernández, W., Spodine, E., Beyer, L., Schröder, U., Richter, R., Ferreira, J. \& Pavani, M. 2005. Synthesis, characterization and antitumor activity of copper(II) complexes, $\left[\mathrm{CuL}_{2}\right]\left[\mathrm{HL}^{1-}\right.$ $\left.{ }^{3}\right]$ =N,N-Diethyl-N'-(R-Benzoyl)Thiourea $(\mathrm{R}=\mathrm{H}, \mathrm{o}-\mathrm{Cl}$ and p-NO $\left.{ }_{2}\right)$. Bioinorganic Chemistry and Applications 3(3-4): 299-316.

Halim, N.I.M., Kassim, K., Fadzil, A.H. \& Yamin, B.M. 2011. Synthesis, characterization and antibacterial studies of benzoylthiourea derivatives. 2nd International Conference on Chemistry and Chemical Engineering 14: 55-59.

Kavak, G., Ozbey, S., Binzet, G. \& Nevzat, K. 2009. Synthesis and single crystal structure analysis of three novel benzoylthiourea derivatives. Turkish Journal of Chemistry 33: 857-868.

Khairul, W.M., Tukimin, N. \& Rahamathullah, R. 2016. Synthesis, characterization and electrical properties of $\mathrm{N}$-([4-(aminophenylethynyl)toluene]-N'-(cinnamoyl) thiourea (AECT) as single molecular conductive film. Sains Malaysiana 45(5): 825-831. 
Khairul, W.M., Faisol, S.L.M., Jasman, S.M., Che Soh, S.K. \& Shamsuddin, M. 2014. Catalytic studies featuring palladium(II) benzoylthiourea derivative as catalyst in sonogashira reaction. Bulletin of Chemical Reaction Engineering and Catalysis 9(3): 241-248.

Kime-Hunt, E., Spartalian, K., DeRusha, M., Nunn, C.M. \& Carrano, C.J. 1989. Synthesis, characterization and molecular structures of a series of [(3,5-Dimethylpyrazolyl)borato] vanadium(III) and -(IV) complexes. Inorganic Chemistry 28: 4392-4399.

Kripal, R. \& Shukla, S. 2009.4 symmetry crystal field and ground state wavefunction of the $\mathrm{VO}^{2+}$ Ion. Chinese Physics Letter 26(8): 26-29.

Li, Z.P., Xing, Y.H., Cao, Y.Z., Zeng, X.Q., Ge, M.F. \& Niu, S.Y. 2009. Synthesis, structure and properties of a series of scorpionate oxovanadium(IV)-carboxylate complexes. Polyhedron 28(4): 865-871.

Limban, C., Marutescu, L. \& Chifiriuc, M.C. 2011. Synthesis, spectroscopic properties and antipathogenic activity of new thiourea derivatives. Molecules (Basel, Switzerland) 16(9): 7593-7607.

Mark Lee, W.F., Pui, L.K., Heng, L.Y. \& Kassim, M. 2013. Molybdenum complex as potential photosensitiser for direct water splitting. Materials Science Forum 756: 231- 237.

Mark Lee, W.F., Ng, K.H., Lorna, J.M., Umar, A.A. \& Kassim, M. 2012a. Penentuan aras jalur tenaga kompleks tungsten nitrosilditiolena. Sains Malaysiana 41(4): 439-444.

Mark Lee, W.F., Lorna, J.M. \& Kassim, M. 2012b. Sifat fotokimia kompleks molibdenum ditiolena. Sains Malaysiana 41(5): 597-601.

Maia, P.I.D.S., Pavan, F.R., Leite, C.Q.F., Lemos, S.S., de Sousa, G.F., Batista, A.A., Nascimento, O.R., Ellena, J., Castellano, E.E., Niquet, E. \& Deflon V.M. 2009. Vanadium complexes with thiosemicarbazones: Synthesis, characterization, crystal structures and anti-mycobacterium tuberculosis activity. Polyhedron 28(2): 398-406.

Mangalam, N.A. \& Kurup, M.R.P. 2009. Synthesis and spectral investigations of vanadium(IV/V) complexes derived from an ONS donor thiosemicarbazone ligand. Spectrochimica Acta. Part A, Molecular and Biomolecular Spectroscopy 71(5): 2040- 2044.

Maurya, M.R., Kumar, A., Abid, M. \& Azam, A. 2006. Dioxovanadium(V) and $\mu$-oxo bis[oxovanadium(V)] complexes containing thiosemicarbazone based ONS donor set and their antiamoebic activity. Inorganica Chimica Acta 359(8): 2439-2447.

McCleverty, J.A., Seddon, D., Bailey, N.A. \& “Joe” Walker, N.W. 1976. The chemistry of cyclopentadienyl and related nitrosyl complexes of molybdenum. Part V. dihalogenonitrosyl[tris( $p$ yrazolyl)borato]molybdenum complexes, their alcoholysis, and the crystal structure of chloronitrosylisopropoxo[tris(4chloro-3,5-dimethylpyraz. Dalton Transactions 10: 898-908.

Nguyen, H.H. \& Abram, U. 2007. Rhenium and technetium complexes with $\mathrm{N}, \mathrm{N}$-dialkyl-N'-benzoylthioureas. Inorganic Chemistry 46(13): 5310-5319.

Parihar, S., Pathan, S., Jadeja, R.N., Patel, A. \& Gupta, V.K. 2012. Synthesis and crystal structure of an oxovanadium(IV) complex with a pyrazolone ligand and its use as a heterogeneous catalyst for the oxidation of styrene under mild conditions. Inorganic Chemistry 51: 1152-1161.

Pettinari, C. 2004. Scorpionates: Pinch and Sting the Metal. La Chimica e l'Industria 86(10): 94-100.
Prasad, K.S., Kumar, L.S., Shekar, S.C., Prasad, M. \& Revanasiddappa, H.D. 2011. Oxovanadium complexes with bidentate N, O ligands: Synthesis, characterization, DNA binding, nuclease activity and antimicrobial studies. Chemical Sciences Journal 12: 1-10.

Rauf, M.K., Imtiaz-ud-Din, Badshah, A., Gielen, M., Ebihara, M., Vos, D.D. \& Ahmed, S. 2009. Synthesis, structural characterization and in vitro cytotoxicity and anti-bacterial activity of some Copper(I) complexes with N,N'-disubstituted thioureas. Journal of Inorganic Biochemistry 103(8): 11351144.

Saeed, A., Flörke, U. \& Erben, M.F. 2014. A review on the chemistry, coordination, structure and biological properties of 1-(acyl/aroyl)-3-(substituted) thioureas. Journal of Sulfur Chemistry 35(3): 318-355.

Saeed, S., Rashid, N., Jones, P.G., Ali, M. \& Hussain, R. 2010. Synthesis, characterization and biological evaluation of some thiourea derivatives bearing benzothiazole moiety as potential antimicrobial and anticancer agents. European Journal of Medicinal Chemistry 45(4): 1323-1331.

Shardin, R., Tan, S.S. \& Kassim, M.B. 2017. Synthesis and structural characterization of N-bromobenzoyl-N'-(1,10phenanthroline-5-yl)thiourea derivatives. Malaysian Journal of Analytical Sciences 21(1): 60-71.

Solinas, A., Faure, H., Roudaut, H., Traiffort, E., Schoenfelder, A., Mann, A., Manetti, F., Taddei, M. \& Ruat M. 2012. Acylthiourea, acylurea, and acylguanidine derivatives with potent hedgehog inhibiting activity. Journal of Medicinal Chemistry 55(4): 1559-1571.

Tan, S.S., Al-Abbbasi, A.A., Tahir, M.I.M. \& Kassim, M.B. 2014. Synthesis, structure and spectroscopic properties of cobalt(III) complexes with 1-benzoyl-(3,3-disubstituted) thiourea. Polyhedron 68: 287-294.

Wiberg, K.B. \& Wang, Y. 2011. Transition metal-catalyzed formation of C-O and C-S bonds. Arkivoc 2011(5): 45-56.

Wlodarczyk, A., Richardson, R.M., Ward, M.D., Mccleverty, J.A., Hursthouse, M.H.B. \& Coles, S.J. 1996. Complexes of tris (3, 5-Dimethylpyrazolyl)borates alkylated on the 4-position of the pyrazolyl rings. X-ray crystal structure of molybdenum dicarbonyl nitrosyl trus(3,5-dimethyl-4-n-butylpyrazolyl) borate. Polyhedron 15(1): 27-35.

Xing, Y., Zhang, Y., Sun, Z., Ye, L., Xu, Y., Ge, M., Zhang, B. \& Niu, S. 2007a. Two new scorpionates vanadium haloperoxidases model complexes: Synthesis and structure of $\mathrm{VO}\left(\mathrm{O}_{2}\right)(\mathrm{pzH})\left(\mathrm{HB}(\mathrm{pz})_{3}\right)$ and $\mathrm{VO}\left(\mathrm{O}_{2}\right)(\mathrm{pzH})\left(\mathrm{B}(\mathrm{pz})_{4}\right)(\mathrm{pzH}$ $=$ pyrazole $\left(\mathrm{C}_{3} \mathrm{H}_{4} \mathrm{~N}_{2}\right)$ ). Journal of Inorganic Biochemistry 101(1): 36-43.

Xing, Y., Bai, F.Y., Aoki, K., Sun, Z. \& Ge, M.F. 2007b. Syntheses and structures of oxovanadium (IV) complexes, $\mathrm{HB}(\mathrm{pz})_{3} \mathrm{VO}(\mathrm{ph}-\mathrm{acac})_{2} \mathrm{H}_{2} \mathrm{O}(\mathrm{pz}$, pyrazole $)$ and $\mathrm{HB}(3,5-$ $\left.\mathrm{Me}_{2} \mathrm{pz}\right)_{3} \mathrm{VO}(\mathrm{ph}-\mathrm{acac})_{2} \mathrm{H}_{2} \mathrm{O}$ and $\mathrm{V}_{2} \mathrm{O}_{4}\left[\mathrm{HB}(\mathrm{pz})_{3}\right]_{22} \mathrm{CH}_{3} \mathrm{CN}$. Synthesis and Reactivity in Inorganic, Metal-Organic and Nano-Metal Chemistry 37(3): 203-211.

Yadava, A.K., Yadav, H.S., Yadav, U.S. \& Rao, D.P. 2012. Synthesis and structural characterization of novel square pyramidal oxovanadium (IV) complexes with ligands. Turkish Journal of Chemistry 36: 624-630.

Yang, W., Liu, H., Li, M., Wang, F., Zhou, W. \& Fan, J. 2012. Synthesis, structures and antibacterial activities of benzoylthiourea derivatives and their complexes with cobalt. Journal of Inorganic Biochemistry 116: 97-105. 
Syahidah Mohd Tahir, Aisha Al-Abbasi, Qurnisha Ghazali \& Mohammad B. Kassim*

School of Chemical Sciences and Food Technology

Faculty of Science and Technology

Universiti Kebangsaan Malaysia

43600 UKM Bangi, Selangor Darul Ehsan

Malaysia

Khuzaimah Arifin \& Mohammad B. Kassim*

Fuel Cell Institute

Universiti Kebangsaan Malaysia

43600 UKM Bangi, Selangor Darul Ehsan

Malaysia
*Corresponding author, email: mb kassim@ukm.edu.my

Received: 21 September 2017

Accepted: 4 March 2018 